\title{
RETHINKING COLORBLIND STATE ACTION: A THOUGHT EXPERIMENT ON RACIAL PREFERENCES
}

\author{
MICHELE GOODWIN* \\ NEVIN GEWERTZ**
}

I

INTRODUCTION

The Supreme Court's most recent affirmative-action opinion, Parents Involved in Community Schools v. Seattle School Dist. No. 1, ${ }^{1}$ suggests a new social climate in education reform-one in which government-forced integration in schools is no longer necessary, or at least not the best idea. Solutions to poor performance in African American schools may now constitutionally fall squarely within the confines of their community. ${ }^{2}$ Indirectly, one might view this as a call to a Black self-help model. That concept is not new; rather it is an old idea most notably perfected during the Montgomery Bus Boycotts. Ironically, a self-help concept seems to have traction across a broad political spectrum, from Derrick Bell, who postulates that inequity derives from social discrimination that is best ameliorated by large-scale government intervention, ${ }^{3}$ to conservatives in the judiciary, notably Justice Thomas of the U.S. Supreme Court. ${ }^{4}$ The historical legacy and controversy of a Black self-help

Copyright (C) 2009 by Michele Goodwin and Nevin Gewertz.

This article is also available at http://law.duke.edu/journals/lcp.

* Everett Fraser Professor of Law and Professor of Medicine and Public Health, University of Minnesota. Gratitude is owed to Trina Jones and the terrific students at Duke Law School, particularly Jeffrey Mason and Ingrid Kaldre. I would also like to thank Katherine Shea for her thoughtful engagement and spirited manner in bringing this project to its conclusion. I am also grateful to my former student Nevin Gewertz for an engaged, thoughtful collaboration.

** J.D., University of Chicago (2009); B.S., B.A. Stanford University (2003).

1. 551 U.S. 701 (2007).

2. We describe the Supreme Court's action in Parents Involved as "race negative," meaning that the Court is attempting to generate a policy that involves race as a decoupling device. In other words, the Court is urging a policy that treats race as a nonessential factor for government policy consideration in a specific domain. Essentially, race is neutralized in such policies. Under "race positive" policies, on the other hand, the government is seeking to protect or advance its state interests by considering race.

3. See, e.g., Derrick Bell, AND We ARE Not SAVEd 217-33 (1987) (commentary regarding affirmative-action policy in particular); see generally DERRICK BELL, SILENT COVENANTS: BROWN V. BOARD OF EDUCATION AND THE UNFULFILLED HOPES OF RACIAL REFORM (2004); Derrick A. Bell, Jr., A Prophecy for Effective Schooling in an Uncaring World, 27 B.C. THIRD WORLD L.J. 1 (2007).

4. See e.g., Grutter v. Bollinger, 539 U.S. 306, 349 (2003) (Thomas, J., concurring in part and dissenting in part). For a more journalistic account of Justice Thomas's position, see Carl Rowan, 
model dates back to the W.E.B. DuBois and Booker T. Washington debates, which concerned whether Blacks would come to rely on their own industry and hard work within a segregated United States or instead organize around integrationist principles. ${ }^{5}$

As scholars conjecture about the future impact of Parents Involved, most locate their discussion within the contexts of public schooling, overlooking the behemoth lurking beneath this pivotal decision. ${ }^{6}$ To consider the decision as being meaningful only to the narrow context of public-school policy overlooks the legal context and social climate in which the decision was rendered. ${ }^{7}$ Such a narrow reading of Parents Involved fails to appreciate the broader, potential policy implications stemming from the decision-policy implications that will likely affect many areas in which government decision-making relates to race. If this prediction is correct, there may be very useful, novel policies to emerge from decoupling race in government-sponsored programs. Perhaps Blacks will be better off foregoing government interventions in some contexts and worse off in others.

In this article, we consider one slice of this decoupling by examining a pressing healthcare issue for all Americans, but especially for Blacks: organ transplantation. Organs are a scarce resource. Commentators describe organ transplantation as being at a "crisis" stage in the United States as Americans participate increasingly in underground illegal markets in China, India, Brazil, and other South American countries. ${ }^{8}$ Organ demand has increased in the past twenty years while organ supply has remained relatively constant. In 2006,

Wrong Man For The EEOC, WASH. Post, Jul. 14, 1982, at A21; The Supreme Court; Clarence Thomas in His Own Words, N.Y. TIMES, Jul. 2, 1991, at A14. Thomas's speech to the Heritage Foundation provides a salient example of the interaction of Thomas's own personal history and his highly individualistic stance. Clarence Thomas, Why Black Americans Should Look to Conservative Policies, Washington, D.C., Jun. 18, 1987, available at http://www.heritage.org/Research/PoliticalPhilosophy/ upload/92685_1.pdf.

5. Compare Booker T. Washington, Address at the Opening of the Cotton States' Exposition in Atlanta, Ga., September 1895, in SELECTED SPEECHES OF BOOKER T. WASHINGTON 32-36 (E. Davidson Washington ed., 1932), with W.E.B. DuBoIs, BLACK RECONSTRUCTION IN AMERICA 708 (1935).

6. See e.g., john a. powell \& Stephen Mendendian, Parents Involved: The Mantle of Brown, The Shadow of Plessy, 46 U. LOUISVILLE L. REV. 631, 663 (2008); Theodore M. Shaw, Parents Involved in Community Schools v. Seattle School District No. 1, 1655 PRACTICING LAW InSTITUTE 11, 64 (2008); john a. powell \& Stephen Mendendian, Little Rock and the Legacy of Dred Scott, 52 ST. LOUIS U. L.J. 1153, 1183 (2008).

7. As Justice Sandra Day O'Connor emphasized five years earlier in Grutter, forced integration will not be given deference by the Court, and only well-tailored affirmative-action plans in higher education will pass constitutional muster. Grutter, 539 U.S. at 332.

8. Underground markets can lead to human-rights violations. See Christian Williams, Note, Combating the Problems of Human Rights Abuses and Inadequate Organ Supply Through Presumed Donative Consent, 26 CASE W. RES. J. INT'L L. 315, 315 (1994). As a result of the influx of global demand, certain countries, including Egypt, have passed laws banning the sale of kidneys to foreigners. Clarisse Lucas, Egypt Becomes Crossroads for Trade in "Human Spare Parts," AgENCE France PRESSE, Jan. 26, 1992. 
approximately 53,000 people added their names to organ waitlists.' Waitlist additions increase on average by 10 percent per year. ${ }^{10}$ Yet only 14,755 organs became available for transplant in 2006, an increase of only 3 percent from the year before. ${ }^{11}$ The organ-supply problem is not simple, and a backlog is developing on organ waitlists. Increases in government spending for advertisement campaigns promoting organ donation have not helped. ${ }^{12}$ More than 100,000 Americans are now waiting for organs in the United States, and it is estimated that soon the wait for some will be ten years. ${ }^{13}$ The problem is acute among Blacks, who comprise one third of patients on the nation's kidney waitlists. ${ }^{14}$ They wait longer than all other groups ${ }^{15}$ and, while waiting, suffer the highest death rates of any other race on the national kidney waitlists. ${ }^{16}$ Some argue that if more Blacks participated as organ donors, their involvement would alleviate the organ shortage among them. But our research proves otherwise, at least in the current donation and allocation system, which does not allow donors to select recipients by race.

9. The Organ Procurement and Transplant Network, Waiting List Additions by Ethnicity, http://www.optn.org/latestData/rptData.asp (last visited Dec. 2, 2007) (choose category "waiting list additions" and organ as "all" and count "candidates" and select "organ by ethnicity.").

10. Id. Percentage change was calculated by dividing the marginal increase in individuals added to organ waitlists over the total number of yearly additions and multiplying by $100 \%$.

11. Id.

12. This is not surprising, however, as the decision to donate an organ either while living or post mortem is complex and personal, likely insulated from the techniques that make advertisement persuasive. Increasing organ supply requires a government response more sensitive to the full complexities of the problem. Deciding to donate an organ is not the same as deciding where to shop for holiday gifts. Individuals cannot be expected to respond to advertisement in the same way. See generally, Assessing Initiatives to Increase Organ Donation, Hearing before the H. Subcomm. on Oversight and Investigation, Comm. on Energy and Commerce, 108th Cong. 1, 36 (2003) (prepared statement of Richard M. Devos) ("Educational campaigns, advertisements, enrollment drives, and all the methods tried up to now have yielded less than $40 \%$ of the population signing, where available, on the back of driver's licenses or donor cards, and proportionally even less people joining potential donor organizations.").

13. For an interesting study projecting future demand for kidneys in the United States, see Benjamin E. Hippen, In Defense of a Regulated Market in Kidneys from Living Vendors, 30 J. MED. \& PHIL. 593, 593 (2005). Projections for patients with end-stage renal disease show a graver estimate. See Jay L. Xue et al., Forecast of the Number of Patients with End-Stage Renal Disease in the United States to the Year 2010, 12 J. AM. SOC'Y NEPHROLOGY 2753-58 (2001).

14. Blacks currently comprise $34.8 \%$ of those awaiting kidney transplants. The Organ Procurement and Transplant Network, supra note 9; see also Christopher F. Bryan et al., Allocation of Kidneys to Afro-American Patients is Proportional to Wait-list Composition, 28 TRANSPlANT PROC. 219-20 (1996); Anthony J. Langone \& J. Harold Helderman, Disparity Between Solid-Organ Supply and Demand, 349 NEW ENG. J. MED. 704 (2003) ("Increasing the number of black donors would not, by itself, alleviate these inequities, since the organs would be distributed in accordance with their proportionate representation on the waiting list.").

15. In 2003-2004 the median waiting time for kidneys was 1313 days for Whites but 1826 days for Blacks. Organ Procurement and Transplant Network, All Kaplan-Meier Median Waiting Times for Registrations Listed: 1999-2004, http://www.optn.org/latestData/rptStrat.asp (last visited Apr. 30, 2007).

16. Organ Procurement and Transplant Network, Death Removals by Ethnicity by Year, http://www.optn.org/latestData/rptData.asp (last visited Feb. 11, 2007). 
Economists, lawmakers, and politicians alike debate how best to increase organ supply. The current system for organ procurement is altruistic and frames the issue as one of "donation" or "gift-giving." As an alternative, a motley crew of academics proposes using incentives to promote organ donation. ${ }^{17}$ They suggest that creating an organ market will increase supply. ${ }^{18}$ But, like the current system of altruistic organ donation, the market solution has drawbacks. Critics warn that financial incentives will commoditize organs and create the potential for economic coercion, such as selling organs to escape debt. ${ }^{19}$ In particular, they forecast that those most likely to suffer injury from financial incentives will be Blacks and the poor. In this article, we step aside from the incentives debate, as the limits of altruistic organ donation are well-vetted elsewhere.$^{20}$ Instead, we consider a thought experiment that shifts control over organ allocation from donor institutions to individual donors by allowing them to select the race of their potential recipients. We examine the utility of allowing Blacks to select other Blacks (or any group they choose) as the recipients of their organs. ${ }^{21}$

Further, we hypothesize that by reducing organ demand among Blacks (by increasing the number of Blacks donating directly to others in their communities), all transplant-waitlist patients will benefit, for organs that may have randomly been assigned to Blacks could be provided to others. Grounded in the new-legal-realism approach to public-policy questions, ${ }^{22}$ we advocate

17. E.g., Michele Goodwin, Black Markets (2006) [hereinafter Goodwin, Black MARKETS]; Gary S. Becker \& Julio J. Elias, Introducing Incentives in the Market for Live and Cadaveric Organ Donations, 21 J. ECON. PERSP. 3 (2007); Richard Epstein, Organ Transplants: Is Relying on Altruism Costing Lives?, AM. ENTERPRISE 50 (1993); Sally Satel, Op-Ed, Death's Waiting List, N.Y. TIMES, May 15, 2006, at A21.

18. Becker \& Elias, supra note 17 , at 3.

19. See Lainie Friedman Ross \& E. Steve Woodle, Ethical Issues in Increasing Living Kidney Donations By Expanding Kidney Paired Exchange Programs, 69 TransPlanTATION 1539, 1542 (2000); Francis Delmonico et al., Ethical Incentives-Not Payment-for Organ Donation, 346 NEW ENG. J. MED. 2002-05 (2002); see also Gilbert Meileander, Gifts of the Body, NEW ATLANTIS (Summer 2006). Yet it is important to evaluate whether such drawbacks justify the current legal prohibition against the exchange of consideration for organs given the number of lives potentially saved by increases in supply.

20. See, e.g., Goodwin, Black MARKeTs, supra note 17; Sally L. Satel \& Benjamin E. Hippen, When Altruism is Not Enough: The Worsening Organ Shortage and What it Means to the Elderly, 15 ELDER L. J. 153, (2007).

21. If social injustices result, the policy proposal may do more harm than good. But this is an empirical question as to whether utilization of racial preferences will be detrimental to general race relations. And it is a separate normative question as to whether marginal decreases in race relations are more valuable than gains in organ supply.

22. The new-legal-realism approach is commonly associated with the use of empirical models and testable hypotheses to understand the impetus behind judicial opinions. See, e.g., Thomas J. Miles \& Cass R. Sunstein, Do Judges Make Regulatory Policy? An Empirical Investigation of Chevron, 73 U. CHI. L. REV. 823 (2006). However, the new-legal-realist approach is also used by scholars in other contexts. See, e.g., Thomas W. Mitchell, Destabilizing the Normalization of Rural Black Land Loss: A Critical Role for Legal Empiricism, 2005 WIS. L. REV. 557 (2005); Gregory C. Shaffer, A New Legal Realism: Method in International Economic Law Scholarship, (Minn. Legal Studies Research Paper No. 09-02), available at $\mathrm{http}: / /$ ssrn.com/abstract=1105498 (forthcoming). 
piercing the veil of ignorance behind which less socially responsive policy is formed and argue for regulations that reflect the concerns and sensitivities of those individuals whom they affect.

In part II, we analyze effects of the current organ-allocation system on Blacks. Our analysis suggests that the current system's discriminatory impact coupled with a well-documented history of medical exploitation experienced by Blacks predisposes members of that community to distrust the organ-transfer system as a whole. This distrust in turn creates a disincentive for Blacks to become organ donors. Part III captures the crux of our thought experiment. In this section, we describe and contextualize the race-preference hypothesis. Part IV forecasts and responds to the primary legal objections that such a policy proposal might engender, most notably that such a system violates the altruistic mandate of the National Organ Transplant Act (NOTA) ${ }^{23}$ or that the use of racial criteria is unconstitutional. Part $\mathrm{V}$ concludes.

\section{II}

\section{RACIAL PREFERENCES AND ORGAN-TRANSFER SYSTEMS: AN EMPIRICAL STUDY AND A PROPOSAL}

Proponents of radical changes in the U.S. organ-transplant system often claim that NOTA creates significant barriers to increasing organ supply. NOTA, they claim, is too restrictive. ${ }^{24}$ They are right. NOTA prohibits exchanging organs for "valuable consideration." ${ }^{25}$ Violation of NOTA can result in a felony conviction carrying a five-year prison term and $\$ 50,000$ fine. ${ }^{26}$ Read broadly, "valuable consideration" extends beyond financial exchanges to encompass direct donations ${ }^{27}$ and solicited donations. ${ }^{28}$ Only recently have

23. The National Organ Transplant Act of 1984, Pub. L. No. 98-507, 98 Stat. 2339 (codified as amended at 42 U.S.C. $\$ \S 201,273-74$ (2006)).

24. See, e.g., Michele Goodwin, Confronting the Limits of Altruism: A Response to Jake Linford, 2 St. Louis U. J. HeAlth L. \& PoL'y 327 (2009); Robert Steinbuch, Kidneys, Cash, and Kashrut: A Legal, Economic, and Religious Analysis of Selling Kidneys, 45 Hous. L. REV. 1529 (2009); Eugene Volokh, Medical Self-Defense, Prohibited Experimental Therapies, and Payment for Organs, 120 HARV. L. REV. 1813 (2007).

25. NOTA, supra note 23 at $\S 274(\mathrm{e})(\mathrm{a})$.

26. Id. at $\S 274(\mathrm{~b})$.

27. Though direct donations do not involve monetary transfer, given the international black market in organ trade, there is a shadow market price (value) inherent in the exchange itself. See generally Charles T. Calstrom \& Christy D. Rollow, The Rationing of Transplantable Organs: A Troubled Lineup, 17.2 CATO J. 163, (1997). But see Memorandum Opinion for the General Counsel Department of Health and Human Services, Legality of Alternative Organ Donation Practices Under 42 U.S.C. $\$ 274(\mathrm{e}) 31$ Op. Off. Legal Counsel 1 (2000), available at http://www.justice.gov/ olc/2007/organtransplant.pdf. (memorandum concluding certain arrangements for donations of kidneys by living donors do not involve "valuable consideration").

28. Arthur Caplan argues that solicited donation undercuts the "ability of the system to get organs to those most in need." ARTHUR CAPLAN, HEALTH, DISEASE, AND ILLNESS: CONCEPTS IN MEDICINE (2004). But see Richard A. Epstein, The Human and Economic Dimensions of Altruism: The Case of Organ Transplantation, 37 J. LEGAL STUD. 459 (2008). (In relevant part, Epstein analyzes the effect of organ solicitation on the supply and demand of organs.). 
paired donations been lifted from the offensive-crimes category. ${ }^{29}$ Some doctors and hospitals refuse to perform these alternative transplants, arguing that even if the law is not enforced as to them, these types of donations violate the spirit of the transplant policy and harm the interests of waitlist patients. ${ }^{30}$ Nor does it appear that the United Network for Organ Sharing (UNOS), the organization that coordinates organ-transplantation policy for the U.S. government, is sympathetic to these entrepreneurial efforts to increase organ supply. ${ }^{31}$ Programs caught under this type of scrutiny include novel Internet sites like Matchingdonor.com, which works like a cross between Facebook and a dating web site. Patients post their stories and potential donors read their biographies, looking for the story that triggers a connection or empathy. ${ }^{32}$

\section{A. The Discriminatory Impact of the Current Organ-Transfer System}

The current organ-allocation system is a colorblind process that relies on Human Leukocyte Antigen (HLA) matching of donors and recipients to determine the priority for individuals awaiting organs. ${ }^{33}$ HLA are antigens found on the surface of all cells, including kidney cells and the cells of other organs available for donations. ${ }^{34}$ These antigens help the human body determine if an object is foreign. ${ }^{35}$ This information then helps the immune system determine whether to fight new cells entering the body. ${ }^{36}$ Differences between

29. Charlie W. Norwood Living Organ Donation Act, Pub. L. No. 110-144 (2007). The paireddonor arrangement is at its core a quid pro quo situation. Two donors each provide a kidney to the other's intended recipient. Thus this form of donation resembles most the arm's length contract arrangement presumably prohibited by NOTA. The UNOS does not find valuable consideration in any living donor arrangement. See Williams Mullen, Position Statement: Kidney Paired Donations, Kidney List Donations and NOTA $\S 301$, Sept. 18, 2006, at 3, http:// www.unos.org/ ContentDocuments/NOTA_301_Position_Paper_-_September_18,_2006.pdf. Senator Carl Levin has introduced The Living Kidney Organ Donation Clarification Act, to clarify "ambiguous language" in Section 301 of NOTA. The bill seeks to assure that kidney paired donation is not the purchase of an organ. See Bills Clarifying Kidney Paired Donation Doesn't Violate NOTA's Valuable Consideration Ban Introduced in Congress, TRANSPLANT NEWS, Feb. 2007, http://findarticles.com/p/articles/ mi_m0YUG/is_/ai_n24241971.

30. See Organ Donor Club Grows, Has Critics, UNITED Press INT'L, June 14, 2006 (“Dr. Douglas Hanto of Harvard Medical School said organs should go to the person who needs it the most, not to people because they are members of a club."); Virginia Postrel, Editorial, "Unfair" Kidney Donations, FORBES, June 5, 2006, at 124 (quoting Dr. Douglas Hanto regarding Harvard's policy concerning organ transplants that involve solicitation and negotiations outside of the UNOS waitlist process: "[W]e won't do them.").

31. See UNOS, How You Can Help, available at http://www.unos.org/HowYouCanHelp/ promoteOrganDonation (making no mention of entrepreneurial efforts for organ donation).

32. Sarah Robbins, We Love Tom Simon Because... He Donated a Kidney to a Woman He Barely Knew, GLAMOUR, Feb. 2008, available at http://www.matchingdonors.com/life/pdfdocs/Tom3.pdf.

33. See Jed Adam Gross, E Pluribus Unos: The National Organ Transplant Act and Its Postoperative Complications, 8 YALE J. HEALTH POL'Y L. \& ETHICS 145, 157 (2008).

34. Beth W. Colombe, Transplantation Immunology: Histocompatibility, in MANUAL OF ALLERGY AND Immunology Fourth Edition (Daniel C. Adelman, Thomas B. Casale, \& Jonathan Corren eds., 2002).

35. Id.

36. $I d$. 
donor and recipient HLA may cause the body to reject an organ. ${ }^{37}$ For transplantation purposes, however, a donor's HLA does not have to be an exact match to a recipient's HLA. ${ }^{38}$

Thomas Starzyl's groundbreaking study in the Lancet over a decade ago provided compelling evidence that an exact match was not required. Starzyl suggested that matching even between parents and their children gives "no better early or late results than kidneys from randomly matched living spouses or other nonrelatives." ${ }^{39}$ More important, with development of immunosuppressant drugs, organ rejection is less of a concern today than when the HLA-matching system was first developed in $1987 .{ }^{40}$ The problem with organizing transplantation around such an antiquated process is that it reduces the likelihood that donors who are not "perfect" matches will give to third parties.

\section{Table 1: Organ Allocation and Transplantation}

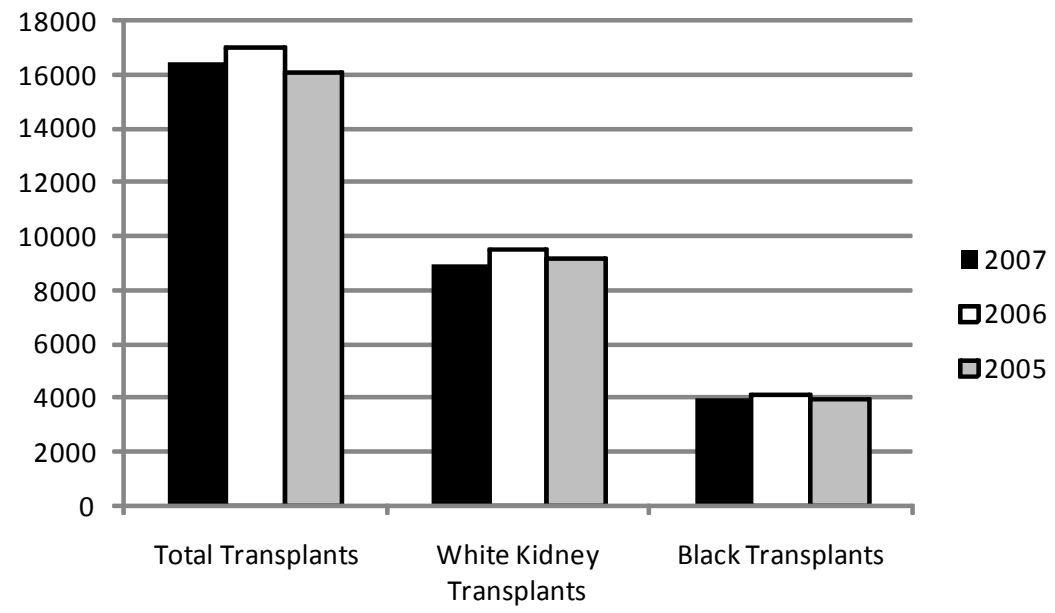

Ironically, despite the color-blind intent and nature of the organ-allocation system, it results in non-race-neutral outcomes by systemically disadvantaging

37. Id.

38. See, e.g., Luis Almenar et al., Influence of HLA Matching on Survival in Heart Transplants, 37 TRANSPLANTATION PROC. 4001 (concluding that "[a] higher degree of HLA-A, -B, and -DR matching did not have a positive effect on heart transplant patient survival, rejection episodes or infection."). For a discussion of HLA matching in kidney transplantations, see Xuanming $\mathrm{Su}$ et al., Diminishing Significance of HLA Matching in Kidney Transplantation, 4 AM. J. TrANSPLANTATION 1501-08 (2004).

39. Thomas E. Strazl \& John J. Fung, The Politics of Grafting Cadaver Kidneys, 348 LANCET 454 (1996).

40. Vikas R. Dharnidharka, Donald M. Stablein, \& William E. Harmon, Post-Transplant Infections Now Exceed Acute Rejection as Cause for Hospitalization: A Report of the NAPRTCS, 4 AM. J. TRAnSPlantATION 3, abstract (2004). See also Margaret R. Sobota, The Price of Life: \$50,000 for an Egg, Why Not \$1,500 for a Kidney? An Argument to Establish a Market for Organ Procurement Similar to the Current Market for Human Egg Procurement, 82 WASH. U. L.Q. 1225, 1226 (2004). 
Blacks. Racial disparities in transplantation waiting times, death rates, and need persist at alarming rates. As of December 15, 2007, 98,117 people in the United States were awaiting organ transplantation. ${ }^{41}$ Blacks comprised $34 \%$ of those awaiting kidney transplants-more than any other single racial group-and $28 \%$ were awaiting organs in general. ${ }^{42}$ Despite comprising approximately onethird of those individuals awaiting organs on organ waitlists, Blacks did not receive a proportionate share of those organs transplanted. Whites received $62.1 \%$ of organ transplantations in 2007, while Blacks and other minorities received $19.3 \%$ and $18.6 \%$ respectively. Table 1 summarizes the disparity between Black composition on the national organ waitlist and as part of the population of individuals receiving organs. Blacks comprise more than onethird of the waitlist, however, they receive less than one third of all organs and less than half the number of organs allocated to White patients. (Table 1).

Our research reveals that the current prioritizing method for the distribution of organs may also contribute to racial disparities. From 1999 through 2004, the median wait time for a kidney for a White patient was 1255 days, whereas for their Black counterparts the median wait time was 1781 days. ${ }^{43}$ Table 2 compares the median waiting time for Blacks and Whites on the UNOS organ wait-list from 1999 through 2004. In addition to longer wait time, Black patients also experience the highest death rate of any ethnic population on the transplant waitlist. ${ }^{44}$ The data in Table 2 demonstrate that the current allocation system "generally ignores African American organ consumers and recipients, and focuses almost exclusively on the quality of their organs as donors." ${ }^{45}$ The disparate impact of contemporary transplant policy is irrefutable. Blacks are systemically at the "back of the bus" for organ transplants and often die as a result.

41. The Organ Procurement and Transplant Network, Data, http://www.optn.org/data/ (last visited Dec. 15, 2007).

42. Id. (choose category "waiting list"; count "candidates"; select "organ by ethnicity") (listing 25,649 African American kidney-transplant candidates, listing 27,659 African Americans awaiting transplant of any organ).

43. Id. (Kidney Kaplan-Meier Median Waiting Times for Registrants Listed 1999-2004, available at http://www.optn.org/latestData/rptStrat.asp (last visited Dec. 15, 2007) (choose category "median waiting time"; choose organ "kidney"; select "waiting time by ethnicity").

44. Id.

45. Michele Goodwin, 2007 Survey of Books Related to the Law: Public Policy: Private Ordering and Intimate Spaces: Why the Ability to Negotiate is Non-Negotiable, 105 MICH. L. REV. 1367, 1371 (emphasis in original). 


\section{Table 2: Mean Waiting Time}

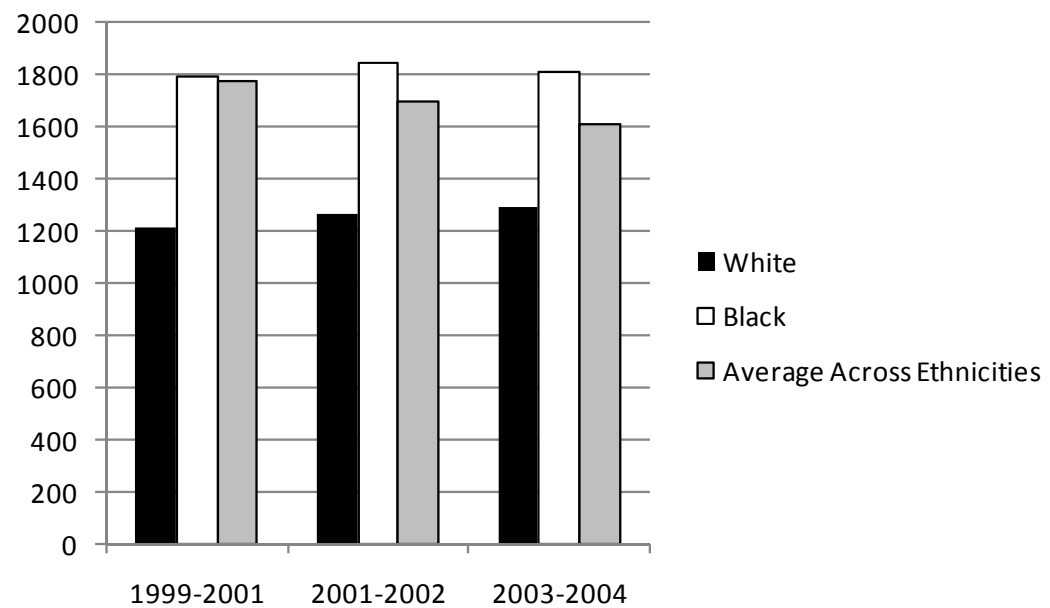

B. Black Distrust of the Organ-Transfer System Creates Disincentives for Participation as Organ Donors

There is limited empirical information available concerning the interplay between the racial disparities present in the organ-allocation process and individual choice on whether to become an organ donor. The available data suggests, at least among Blacks, a strong connection. From 2002 through 2004, the African American Organ Transplant Study I (AAOTS I) conducted an empirical assessment of 588 African Americans' perception of the current altruistic organ-donation system. ${ }^{46}$ The researchers hypothesized that the existing differential between Blacks' approval of organ donation and donor registration was not due to registration obstacles alone, but rather to a more general, but overlooked, "breach of confidence or lack of trust in the current transplantation and procurement system." ${ }^{97}$ The study was followed by forty indepth, qualitative interviews (African American Organ Transplant Study II, (AAOTS II)). Together, the two studies may have answered much more than the question originally addressed. They revealed that a more-subtle race tension exists when Blacks interact with the current organ-procurement- and allocation system- "participants perceived the altruistic process to be manipulative and a veiled effort to sacrifice African Americans to save White Americans." ${ }^{48}$ Ironically, even the more sophisticated study participants-including a banker,

46. African American Organ Transplant Studies I and II (conducted in Chicago) (hereinafter AAOTS I and II). For a discussion of the African American Organ Transplant Studies I and II, see GOODWIN, BLACK MARKETS, supra note 17, at 49-53.

47. GOODWIN, BLACK MARKETS, supra note 17, at 48.

48. Id. 
a physician, a nurse, and school teachers-believed that the transplantallocation system was biased, if not by race then by socio-economic status. ${ }^{49}$

Study participants were generally cynical about whether the UNOS allocation system benefited Blacks. One participant went so far as to suggest that "efforts to encourage African Americans to donate were part of a conspiracy 'because they were going to use Black people as spare parts... when White people are sick . . . they'll have a means to get their organs." ${ }^{50}$ This data suggests that Blacks perceive a lack of control in the altruistic process. D.B., a Chicago area school teacher urged that African Americans should "stay together as a people," implying that African Americans should be able to determine the recipients of their organs. ${ }^{51}$ Allowing for potential donors to control the race, culture, religion, or gender of their recipients may be one way in which an organ-transfer system can provide this type of control. Further data from the AAOTS I and II studies suggest the same:

For example, in AAOTS I when survey participants were asked whether they are registered to donate, only $36 \%$ answered affirmatively. However, when asked whether they would be willing to donate if the recipients were Black, over $58 \%$ answered positively. Thus, the concept of organ sharing is not the problem; fewer than $10 \%$ of those surveyed opposed donation. Indeed, Blacks were more willing to donate when they believed African Americans would be treated equitably in both the procurement and allocation process. ${ }^{52}$

The critical issue for Blacks with regard to organ transplantation may be control, or the perceived lack of it. After being asked whether mandatory donations would benefit African Americans, one participant concluded, "[N]o[,] ... because they are going to give it to the white person." "5is participant suggested that even poorer, working-class Whites would be privileged by receiving organs over their Black counterparts. ${ }^{54}$ Another African American teacher, Y.C., attributed present organ donation among African Americans to the desire to save the lives of other Blacks. According to Y.C.,

49. Interview with D.B., November 21, 2003. D.B., a school teacher, believed that African Americans were lower on the transplant waitlists because of their "socio-economic situation." D.B. also thought African Americans should be paid to donate their organs because of this. He went on to say that financial incentives might be acceptable if it provided a "means of breaking a horrific cycle which your family may be in as far as economics are concerned and you wanted your children to have a better chance at life to be on the same playing field as our white counterparts, I think that it will be a decision that I would make without hesitation ...." Interview with D.B., Chicago, IL (Nov. 21, 2003).

50. Interview with K. (quoted in GOODWIN, BLACK MARKETS, supra note 17, at 50); Interview with D.B., supra note 49.

51. Interview with D.B., supra note 49.

52. GOODWIN, BLACK MARKETS, supra note 17 , at 52 .

53. Interview with S.B., Nov. 21, 2003; Interview with D.B., Chicago, IL (Nov. 21, 2003). S.B. was thirty-four years old when interviewed. She was clear to acknowledge that she would readily surrender a kidney to a relative, but seemed very mistrustful of organ donation in general because she believed African Americans would more likely be passed over on the allocation side.

54. Id. 
African Americans participate in organ donation "because they want to insure that African Americans get the organs that they need." 55

AAOTS-participant responses suggest that the decision to participate in organ transfers is animated by more than the consideration of whether to give. And, in general, many express concern over destroying the sanctity of the human body or the ability to live with one kidney. ${ }^{56}$ Yet at least in the case of Black participants, such choices are also ensnared with broader and complex racial considerations.

Earlier work suggested that the racial undercurrent present in the altruistic organ-transfer system may be due to unintended consequences in the allocation of organs. ${ }^{57}$ Procurement and allocation are intimately interwoven. The system cannot give what it does not have, and how it presently gives has been characterized as pernicious, unfair, and inequitable. ${ }^{58}$ But a deeper racial tension may also be at play. To deter organ donation, actual injustice and inequity in the allocation of organs is not necessary: Blacks' perceptions of the current organ-transfer system as privileging Whites might derive from broader conceptions of social injustice rather than from any particular knowledge of allocation inequity. If this hunch is correct, then even in the face of economic incentives, certain individuals might abstain from participating in the organtransfer system based on concerns about equitable distribution to Blacks. To encourage Black donation, a procurement system would have to compensate individuals not only for the value of their organs, but also for the value of participating in a system that reinforces racial inequalities and social injustice. In contrast, allowing for racial preferences in an incentive model might lead to "discounts" based on race.

C. Past Abuses of Blacks in the Health-Care Context Contribute to the Perceived Inequality

Historical disparities in the treatment of Blacks within the American healthcare system may also contribute to perceptions of racial inequalities and social injustice in the organ transplant system. Distrust among Blacks of the American healthcare system is well-documented. ${ }^{99}$ This distrust may be "a natural and logical response to the history of experimentation and abuse"

55. Interview with Y.C., Oct. 27, 2003.

56. FAQ: Common Concerns about Organ Donation, ReAders Digest, Dec. 2, 2007, http:// www.readersdigest.com.au/content/34604/. Individual participants in the Goodwin study demonstrated similar concerns. See GOODWIN, BLACK MARKETS, supra note 17, at 51.

57. Michele Goodwin, The Body Market: Race Politics and Private Ordering, 49 ARIZ. L. REv. 599, 607-10 (2007) [hereinafter Goodwin, The Body Market]; see generally, GOODWIN, BLACK MARKETS, supra note 17.

58. GOODWIN, BLACK MARKETS, supra note 17, at 53.

59. See, e.g., HARRIET WASHINGTON, MEdicAl APARTHEID: THE DARK History OF MEdicAL EXPERIMENTATION ON BLACK AMERICANS FROM COLONIAL TIMES TO THE PRESENT (2007). 
suffered by Blacks. ${ }^{60}$ The use of Blacks in medical experiments can be traced back to the antebellum period; from slavery to the present, scholars document a troubling medical story that involves medical research and the absence of ethical or scientific protocols to protect the interests of coerced participants. ${ }^{61}$

Among the more indelicate stories illustrating research and medical abuse experienced by African Americans are the gynecological experiments conducted by Marion Sims on enslaved Black women without the aid of anesthesia $^{62}$ and the U.S. Public Health Service study, otherwise known as the infamous Tuskegee Syphilis Study, underwritten by the federal government, and lasting over forty years. ${ }^{63}$ Other incidents of government-sponsored medical studies and experimentation on Blacks included medical sterilizations targeting Black women on welfare and drug testing on Black children in foster care. ${ }^{64}$ Reports about such experiments are troubling but no longer raise the allegation of faulty data, conspiracy theory, or hypersensitivity among Blacks. ${ }^{65}$ Yet other experiments, confirmed by FBI and CIA reports, seem absolutely outlandish and are difficult to understand, as the data collected certainly provided little if any potential medical benefit for Blacks or other Americans. Consider the mosquito studies conducted in Florida and Georgia where mosquitoes were released in Black communities to determine the effectiveness of insect warfare on US Cold War enemies. ${ }^{66}$ Equally the radiation studies, in which Blacks and poor Whites were injected with plutonium by government-funded scientists could hardly be justified to those communities nor meet the international ethical protocols of the time. ${ }^{67}$ Finally, consider Dr. Albert Kligman's

60. Vernellia R. Randall, Slavery, Segregation and Racism: Trusting the Health Care System Ain't Always Easy! An African American Perspective on Bioethics, 15 ST. LOUIS U. PUB. L. REV. 191,191 (1996).

61. E.g., WAShington, supra note, 59 at 7-8. See also Goodwin \& Richardson, Panel Discussion at Duke Law School Symposium: Race and Socio-Economic Class: Unraveling an Increasingly Complex Tapestry (Jan. 23, 2009) (discussing in more detail these experiments, the Tuskegee Study, among other government-sponsored experimentation on Blacks).

62. See generally J. MARION SiMS, THE StORY OF MY LIFE (1968). See also Goodwin \& Richardson, supra, note 61.

63. Stephen B. Thomas \& Sandra Crouse Quinn, The Tuskegee Syphilis Study, 1932 to $1972:$ Implications for HIV Education and AIDS Risk Education Programs in the Black Community, 81 AM. J. Pub. HeAlth 1498, 1499-1502 (1991); see also Randall, supra note 60, at 191 ("The Tuskegee Experiment involved four hundred African American men in a government-sponsored study to research the effects of untreated syphilis. While the men were not deliberately exposed to syphilis, as rumored, they were never told that they were not being treated or that effective treatment was available.").

64. WASHINGTON, supra note 59, at 202-06, 335-37.

65. See, e.g., id. at 9-13, 21-22.

66. Id. at 361-62.

67. See generally CATHy O'Brien \& MARK Phillips, TrAnCE Formation OF AMERICA (1995); Gordon Thomas, Journey into MAdness: The True StOry of SECRET CiA Mind CONTROL AND MEDICAL ABUSE (1989). 
dermatological studies conducted on inmates at Holmesburg Prison, most of whom were Black and did not reap the benefits of study's results. ${ }^{68}$

By comparison, the highly controversial sickle-cell screening programs of the 1960 s and 1970 s seem mundane in their discriminatory reach. Nevertheless, those screening initiatives provide another historical reason for the unease and distrust that some Blacks carry as part of a community medical experience. Often the experiences are not direct (and may be significantly attenuated), but Blacks tend to view the harms, coercion, and fraud experienced by other Blacks as a collective experience. ${ }^{69}$ In other words, these cases serve as warnings. In particular, the sickle-cell screening programs provide a glimpse from a different angle at medical uncertainty.

The sickle-cell screening tests were minimally invasive; however, participants grew concerned about how their medical information might be misused for untoward or unjust purposes:

Some states passed legislation requiring all African American children entering school to be screened for the sickle-cell trait, even though there was no treatment or cure for the sickle-cell disease. Some states required prisoners to be tested, even though there would be no opportunity for them to pass on the trait. Job and insurance discrimination were both real and attempted. The military considered banning all African Americans from the armed services. African American airline stewardesses were fired. Insurance rates went up for carriers. Some companies refused to insure carriers. During that period, many African Americans came to believe that the sicklecell screening initiative was merely a disguised genocide attempt, since often the only advice given to African Americans with the trait was, "Don't have kids."

It is perhaps this fear-rational or not-and grounded in isolated but not infrequent medical fraud, mishaps, and missteps that leads many Blacks to believe that core principles of bioethics (such as autonomy, beneficence, and justice) will not protect them or their families from medical mistreatment. A common thread in more than two centuries of research experimentation on Blacks reveals that the benefits of the studies were not intended for them. ${ }^{71}$ It is also clear that, despite international human research protocols such as the Nuremburg Code, the Declaration of Helsinki, and the Declaration of Geneva, doctors and researchers persisted in unethical medical study involving African Americans, often failing to obtain full, informed consent, or mischaracterizing the nature of the research. Scholars might disagree as to why researchers ignored ethical protocols and well-established legal principles such as informed

68. Jesse Williams describes in horrid detail the transgressions that he suggests were surreptitiously inflicted upon him by Dr. Kligman and his colleagues. Williams describes having skin removed from his underarm to "study the glands," injections of cadaveric tissue in his back, acid rubbed into his scrotum, and many other disturbing research experiments. Unlike many other unwitting participants, Williams was paid three dollars per experiment with Dr. Kligman. WASHINGTON, supra note 59, at 244-45.

69. See Shani M. King, Race, Identity, and Professional Responsibility: Why Legal Services Organizations Need African American Staff Attorneys, 18 CORNELL J.L. \& PUB. POL'Y 1, 31 (2008).

70. Randall, supra note 60, at 201.

71. See, e.g., Michael Laufert, Race and Population-Based Medicine: Drug Development and Distributive Justice, 21 GEO. J. LEGAL ETHICS 859 (2008); R. Slovenko, Milestones in the Evolution of Standards for Experimental Treatment or Research, 25 MED. \& L. 523 (2006). 
consent when working with Blacks. One explanation might be that using Blacks as research subjects proved expedient and economically efficient. Or, given Blacks' fractured legal and social statuses, researchers could expect minimal backlash.

\section{III}

\section{A THOUGHT EXPERIMENT: INCORPORATING RACIAL PREFERENCES IN ORGAN TRANSPLANTATION}

Our theory is that Blacks are less likely to donate organs not because they are less altruistic or fundamentally opposed to such donations, but because of preconceived racial perceptions and fear of bias. If this is correct, then increased spending on government-sponsored advertisements targeted at Blacks will prove ineffective and inefficient. Blacks will not be swayed by the seductive appeal of the "gift of life" or "gift of hope" public-relations advertisements. For them, organ donation is burdened by history and race. Their concerns appear to center on two issues: (1) that doctors will hasten their deaths at time of sickness, which is relevant to cadaveric donations; and (2) whether their organs can save sick Black patients. ${ }^{72}$ If we are correct in assessing the "tipping point" for Blacks in the context of organ donation, it is worth carrying out a thought experiment that assesses whether there is any benefit to incorporating racial preferences in organ transplantation. To this end, we are interested in measuring the social and economic benefits to Black communities and calculating whether there is a government, and therefore larger community, benefit that results from this type of hypothetical policy.

\section{A. Allowing Organ Donors to Choose the Race of their Organ Recipients}

Currently, potential organ donors must respond positively to a single binary question in order to become an organ donor: Do you wish to become an organ donor $?^{73}$ This question creates an all-or-nothing choice. Either an organ donor participates in the organ-procurement system by accepting the current means of organ allocation, including its disparate racial impact, or a potential donor may not donate at all.

Instead of a single question, donor-registration forms could ask respondents to select desired recipients by any set of preferences, including race, by checking one of several boxes. Alternatively, a respondent could simply indicate in writing the desired race of the organ recipient. Respondents who do

72. See Patricia A. King \& Leslie E. Wolf, Empowering and Protecting Patients: Lessons for Physician-Assisted Suicide from the African-American Experience, 82 MinN. L. REV. 1015, 1029 (1998); Jake Linford, The Kidney Donor Scholarship Act: How College Scholarships Can Provide Financial Incentives for Kidney Donation While Preserving Altruistic Meaning, 2 ST. LOUIS U. J. HEALTH L. \& POL'Y 265, 286-87 (2009).

73. Some states also allow organ donors to specify which organs they are willing to donate. E.g., Conn. Dep't of Motor Vehicles, Donor Registration Card, http://www.ct.gov/dmv/lib/dmv/20/29/B142.pdf (last visited Apr. 30, 2008). 
not wish to select a racial preference for the recipient of their organ could abstain from doing so either by affirmatively checking a box indicating this preference or failing to specify a racial preference after indicating their desire to become an organ donor.

In some sense, this thought experiment merely extends existing practices. Private organizations, such as Matchingdonors.com, allow living donors to go online, read profiles of those in need of an organ, look at photos, and select their organ recipient. ${ }^{74}$ Thus, selection on the basis of racial preferences is possible. Moreover, such web sites allow living donors to foster relationships not otherwise available through anonymous, altruistic donation. Though no financial consideration is exchanged, many donor pairs become influential figures in each other's lives. ${ }^{75}$

Might the use of racial preferences to incentivize organ donations have nefarious distributional consequences? Some scholars raise concerns that White donors, who currently comprise the largest percentage of organ donors ${ }^{76}$ will use racial preferences to restrict their donations to Whites. As a result, greater racial inequality in organ allocation will occur than in the current system. Such predictions are plausible but less persuasive in light of our findings. The changes in the ratio of Black kidney recipients to White kidney recipients varies in both number of kidneys available for transplantation and percentage of kidneys directed within each race. ${ }^{77}$ Expressed as a ratio, the current ratio of Black kidney-transplant recipients to White kidney-transplant recipients is 0.375 . In contrast, the ratio of Blacks to Whites awaiting kidney transplantation on the waitlist is 0.88 . 2007).

74. MatchingDonors.com, http://www.matchingdonors.com/life/index.cfm (last visited Dec. 3,

75. See id. (providing Patient and Donor profiles and stories). To the extent that the donor receives existential benefits, "giving the gift of life" is not an entirely selfless act. Value is exchanged; it is simply nonpecuniary in nature.

76. In 2006, 10,190 of the 14,755 donors were White (69.1\%); 2,061 were Black (20.2\%). However, Blacks represent $28.2 \%$ of those awaiting organs. Data includes both living and cadaveric donations. OPTN, Donors Recovered in the US by Donor Type, http://www.optn.org/latestData/rptData.asp (last visited Dec. 3, 2007).

77. The authors would like to thank Professor Thomas Miles for his assistance in conceptualizing and framing the economic analysis outlined in this section. 
Figure 1: Distribution of Current System

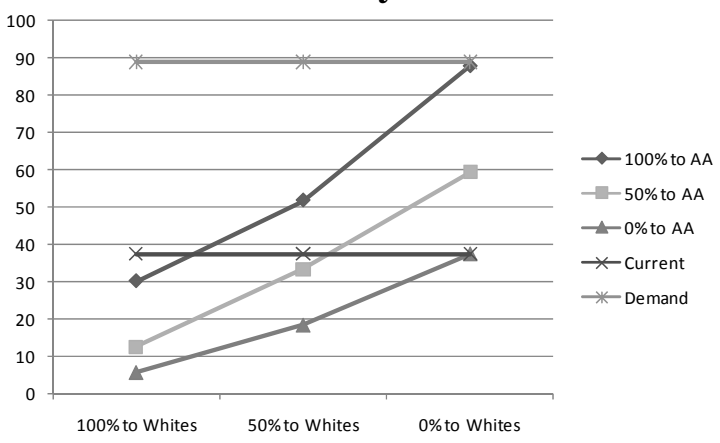

\begin{tabular}{|c|c|c|c|}
\hline & $100 \%$ to Whites & $50 \%$ to Whites & $0 \%$ to Whites \\
\hline $100 \%$ to $A A$ & 30.2 & 51.9 & 87.8 \\
\hline $50 \%$ to $\mathrm{AA}$ & 12.8 & 33.5 & 59.4 \\
\hline $0 \%$ to $A A$ & 5.8 & 18.4 & 37.5 \\
\hline Current & 37.5 & 37.5 & 37.5 \\
\hline Demand & 89.0 & 89.0 & 89.0 \\
\hline
\end{tabular}

Assuming differing rates of directed donation, only a marginal increase in kidney procurement from Blacks is necessary to alter the overall racial equality of organ allocation.

\section{Figure 2: 52\% Black Procurement Rate}

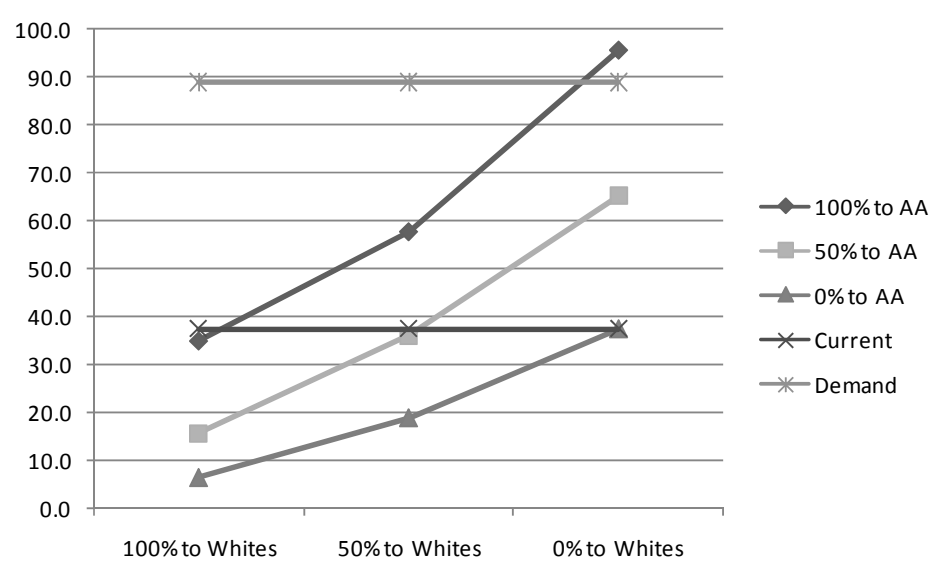

\begin{tabular}{|c|c|c|c|}
\hline & $100 \%$ to Whites & $50 \%$ to Whites & $0 \%$ to Whites \\
\hline $100 \%$ to $A A$ & 35.0 & 57.8 & 95.7 \\
\hline $50 \%$ to $A A$ & 15.8 & 36.1 & 65.3 \\
\hline $0 \%$ to $A A$ & 6.5 & 19.0 & 37.5 \\
\hline Current & 37.5 & 37.5 & 37.5 \\
\hline Demand & 89.0 & 89.0 & 89.0 \\
\hline
\end{tabular}


Figure 3: 75\% Black Procurement Rate

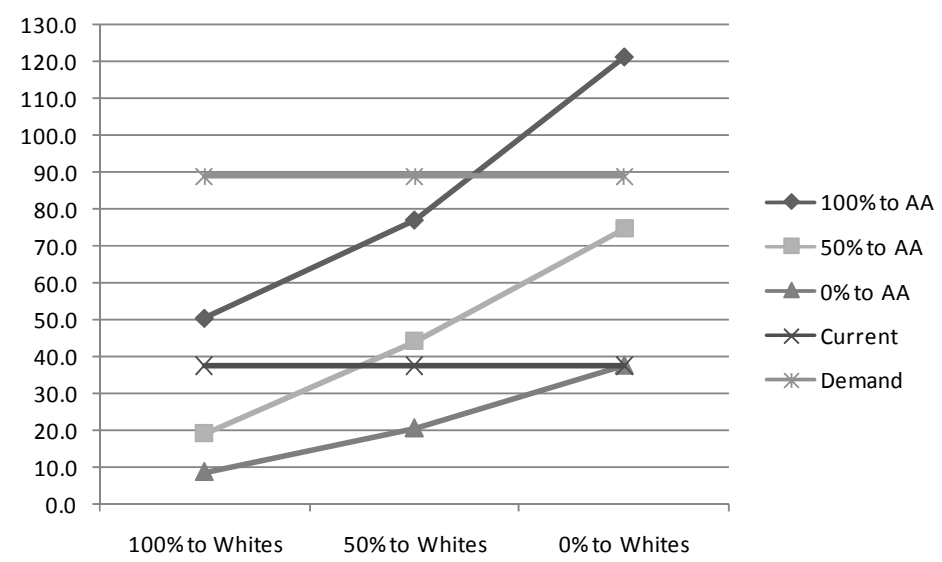

\begin{tabular}{|r|c|c|c|}
\multicolumn{1}{|c|}{} & $\mathbf{1 0 0 \%}$ to Whites & $\mathbf{5 0 \%}$ to Whites & 0\% to Whites \\
\cline { 2 - 4 } $\mathbf{1 0 0 \%}$ to AA & 50.4 & 77.1 & 121.3 \\
\cline { 2 - 4 } $\mathbf{5 0 \%}$ to AA & 19.3 & 44.3 & 74.8 \\
\hline $\mathbf{0 \%}$ to AA & 8.7 & 20.5 & 37.5 \\
\hline Current & 37.5 & 37.5 & 37.5 \\
\hline Demand & 89.0 & 89.0 & 89.0 \\
\hline
\end{tabular}

Figure 4: 52\% Black and White Procurement Rate

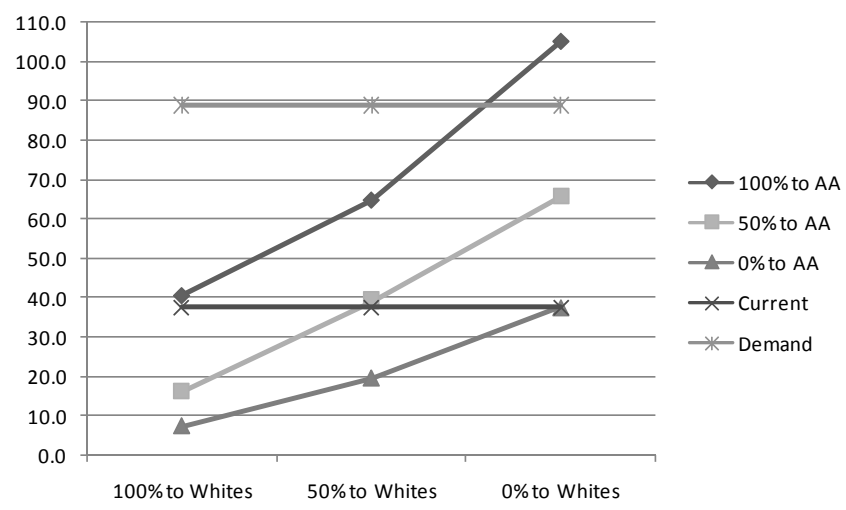

\begin{tabular}{|r|c|c|c|}
\multicolumn{1}{|c|}{} & $\mathbf{1 0 0 \%}$ to Whites & $\mathbf{5 0 \%}$ to Whites & 0\% to Whites \\
\cline { 2 - 4 } $\mathbf{1 0 0 \%}$ to AA & 40.7 & 64.9 & 105.2 \\
\cline { 2 - 4 } $\mathbf{5 0 \%}$ to AA & 16.3 & 39.3 & 65.6 \\
\hline $\mathbf{0 \%}$ to AA & 7.4 & 19.6 & 37.5 \\
\cline { 2 - 4 } Current & 37.5 & 37.5 & 37.5 \\
\cline { 2 - 4 } Demand & 89.0 & 89.0 & 89.0 \\
\cline { 2 - 4 } & & &
\end{tabular}




\section{Figure 5: 52\% Black Participation and 72\% White Participation Rate}

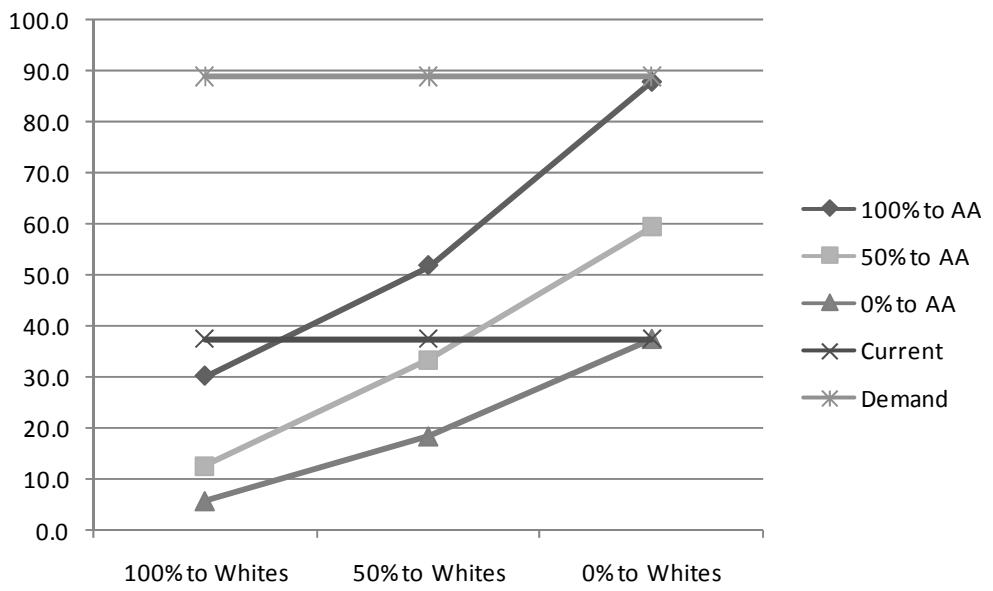

\begin{tabular}{|r|c|c|c|}
\multicolumn{1}{r}{$\mathbf{1 0 0 \%}$ to AA } & $\mathbf{1 0 0 \%}$ to Whites & $\mathbf{5 0 \%}$ to Whites & 0\% to Whites \\
\cline { 2 - 4 } & 30.2 & 51.9 & 87.8 \\
\hline $\mathbf{5 0 \%}$ to AA & 12.8 & 33.5 & 59.4 \\
\hline $\mathbf{0 \%}$ to AA & 5.8 & 18.4 & 37.5 \\
\cline { 2 - 4 } Current & 37.5 & 37.5 & 37.5 \\
\cline { 2 - 4 } Demand & 89.0 & 89.0 & 89.0 \\
\hline
\end{tabular}

For example, in Figure 3, given no increase in absolute number of organs donated, if $50 \%$ of kidneys procured from Blacks are directed to Black recipients, there would be no net increase in allocation inequity even if up to $55 \%$ of kidneys received from White donors are directed to only White recipients.

By contrast, given no increase in absolute number of organs donated, if $50 \%$ of kidneys from Black donors are directed to Black recipients and if only $20 \%$ of kidneys from White donors are directed to White recipients, the allocation ratio of Black kidney recipients to White kidney recipients changes to 0.463. Unsurprisingly, this ratio increases as the percentage of kidneys directed to Black recipients from Black donors increases and the percentage of White within race donation decreases. Thus, even without increasing the actual number of kidneys distributed, a gain in social equity is possible by allowing some amount of directed allocation.

These calculations strongly indicate a few relevant points. First, the choice to direct donation by race might lead to greater equality in organ allocation even without a corresponding increase in overall donor number. Second, the inclusion of racial preferences is likely to stimulate organ donation to minority recipients. Blacks, who do not donate as frequently as Whites, might be drawn 
to donate their organs to Black recipients. ${ }^{78}$ Third, assuming all other racial groups donate organs at the same rate, an increase in the absolute number of Black organ donors can both increase the absolute number of transplantable organs and decrease inequity in the current organ-allocation system, even assuming within-race White donation will occur. Fourth, it is unlikely that the altruistic White donor who contributes without preference to race currently will make animus-based racial decisions simply because the opportunity is available.

Finally, even if the use of racial preferences causes some crowding out by driving potential donors from the current system or encourages some Whites previously unwilling to donate to share organs only within their ethnic community, the net impact will be positive for minorities awaiting transplants. The proportional decrease in demand from waitlisted Whites will increase the probability that waitlisted minorities will receive organs donated on the basis of HLA matching alone and without racial limitations. ${ }^{79}$ Controversial though it may be, objections suggesting that racial preferences will polarize organ disbursement ignore compelling data that current efforts at transracial, colorblind organ transplant policy resultin a persistent racial impact.

\section{B. The Economic Consequences of Including a Racial Preference}

In addition to deaths resulting from unmet organ demand in Black communities, the disparate effect of organ allocation creates economic consequences. For each Black patient on dialysis, his or her family suffers the economic consequences of that lost income. The ripple effect of that economic loss extends to their communities, both through a loss of taxable income for local infrastructure, including schools, and through a loss of philanthropic donation to community organizations, including churches, community centers, and fraternal organizations. These contributions are critical in sustaining healthy, well-functioning, safe communities.

Blacks have considerable spending power, and this has the power to increase. In 2003, Black spending power was estimated at $\$ 636$ billion, ${ }^{80}$ a figure comparable to the gross domestic product of the twentieth-wealthiest country in

78. Black philanthropic preferences may more closely align with church affiliation rather than race. See Alice Gresham Bullock, Taxes, Social Policy, and Philanthropy: The Untapped Potential of Middleand Low- Income Generosity, 6 CORNELL J.L. \& PUB POL'Y 325, 350 (1997) ("Historically, the Black church has been the core of philanthropy in the African American community."). This suggests that religious rather than racial preferences are a more appropriate "framing" to incentivize Black organ donation.

79. This assumes that White transplant recipients, as a group, are prioritized above Blacks on the basis of HLA matching alone. There is reason to believe that this is empirically true on the basis and prevalence of genetic markers in the Black populations. For a discussion of this systemic effect, see GOODWIN, BLACK MARKETS, supra note 17, at 129 (noting higher sensitivities to A, B, and DR antigens in Blacks); Barbara A. Noah, Racial Disparities in the Delivery of Health Care, 35 SAN DIEGO L. REV. 135, 142-47 (1998) (noting higher prevalence of positive crossmatch rate in Blacks).

80. Target Market News: The Black Consumer Authority, http://www.targetmarketnews.com/ buyingpowerstats.htm (last visited Feb. 13, 2008). 
the world-the Netherlands. ${ }^{81}$ In 2006, Black spending power was estimated at $\$ 799$ billion, ${ }^{82}$ a figure comparable to the GDP of the seventeenth-wealthiest country in the world-Australia. ${ }^{83}$ Moreover, the projected percentage increase in Black purchasing power is greater than that of the overall purchasing power in America. ${ }^{84}$ In turn, not only is the economic value of Blacks significant to the American economy as a whole, it is becoming more valuable each day.

In 2004, Blacks accounted for 38.3 million people in the United States ${ }^{85}$ and their GDP per capita was $\$ 17,728 .^{86}$ Even when completely accounting for costs saved from medical care and dialysis treatments, removing just one thousand Blacks from organ waitlists each year could add $\$ 17$ million in purchasing power to the U.S. economy. If 2,225 organs are successfully transplanted, ${ }^{87}$ approximately $\$ 40$ million in purchasing power would be added to the U.S. economy. In addition, considering the federal savings from removing Blacks from dialysis, roughly $\$ 60-\$ 90,000$ is saved per year, per Black patient. ${ }^{88}$ Again, if only 100 African Americans were removed from dialysis, \$6-9 million dollars would be saved in the first year alone. Over five years, the savings could multiply up to \$35-45 million dollars by simply removing 100 African Americans from dialysis. Consequently, if 100 Black patients successfully received a donated organ and were removed from dialysis, the net economic gain over five years could be $\$ 46.7$ million. There is reason to believe that such numbers are underestimated. Transplantation is not only the optimal medical treatment but also the most cost-effective treatment for patients suffering from kidney failure. The federal government funds both dialysis treatment and transplantation procedures for almost all Americans. ${ }^{89}$ Yet, after assuming such burdens, the Health Care Financing Administration noted that transplantation

81. Central Intelligence Agency, The World Factbook, Rank Order-GDP, https://www.cia.gov/library/publications/the-world-factbook/rankorder/2001rank.html (last visited Feb. 13, 2008).

82. See Vicky Eckenrode, Sway at the Supermarket: Minorities in Florida and Georgia are Spending Record Amounts, FLA. TIMES-UniOn, Sept. 1, 2006, at D1.

83. Central Intelligence Agency, The World Factbook, Rank Order-GDP, available at https://www.cia.gov/library/publications/the-world-factbook/geos/as.html.

84. See Jeffrey M. Humphreys, African-American Buying Power by Place of Residence: 1990-1999, GA. BuS. \& ECON. CONDITIONS, at 1-2 (Jul.-Aug. 1998).

85. Black Stats, TARGET MARKET NEWS (2005), available at http://www.targetmarketnews.com/ storyid12080503.htm (see left side of browser window).

86. GDP per capita is calculated by dividing the GDP for African Americans by the number of African Americans present in the United States. In 2004, this meant dividing \$679 Billion by 38.3 Million. Id.

87. See infra note 92 .

88. See, e.g., Michael J. Lysaght, Maintenance Dialysis Population Dynamics, 13 J. AM. SoC. NEPHROLOGY S37, S37 (2002).

89. Congress intended "to provide access to life-saving therapy for all who needed it where the costs of treatment were beyond the means of practically all individuals." See RICHARD A. RETTIG \& Ellen L. MARKs, U.S. DeP'T OF HeAlth \& Human SERVS., IMPlementing THE END-STAGE Renal Disease Program of MedicARe 25 (1981) (Health Care Financing Grants and Contracts Report). 
was the most cost-effective means of treating patients with irreversible kidney failure. ${ }^{90}$ Medicare direct dialysis costs routinely exceed $\$ 55,000$ per patient per year. $^{91}$ Illustratively, congressional efforts to legalize paired kidney donation, which may spur transplants, could save $\$ 500$ million over a ten-year period. ${ }^{92}$

More important, moving Black patients off of dialysis allows them to regain their lives and economic potential. The costs of dialysis extend beyond financial-they impact daily life. Treatments usually take at least three days per week and several hours each session, diminishing both quality of life and work potential. $^{93}$

\section{Quantifying the Increase Organ-Donor Racial Selection Will Have on Supply}

According to recent Gallup poll data, $62 \%$ of Whites are willing to donate organs, whereas the figure falls to $39.2 \%$ among Hispanics and to $31.2 \%$ among Blacks. ${ }^{44}$ The survey cited high levels of distrust among Blacks to account for the low participation rate..$^{95}$ In 2005, the same year that the Gallup survey was conducted, UNOS data revealed that 1136 organs were harvested and transplanted from Black cadavers. ${ }^{96}$ One study suggests that this number

90. See generally R.W. Evans, Organ Transplantation and the Inevitable Debate as to What Constitutes a Basic Health Care Benefit, in CliniCAL TRAnsPlants 359, 359 (J. Michael Cecka \& Paul I. Terasaki eds., 1994).

91. Jay Inslee, Transplant Specialists Urge Full Funding for Organ Donation Legislation, U.S. REP. JAY INSLEE'S ISSUES (May 10, 2005), available at http:/www.house.gov/inslee/issues/ health/organ_donation.html.

92. Organ Donation and Recovery Improvement Act, Pub. L. No. 108-216, 118 Stat. 584 (2004); Press Release, Congressman Jay Inslee, House Honors Fallen Colleague by Passing Kidney-Donation Bill (Mar. 7, 2007), http://www.house.gov/inslee/issues/health/house_passes_norwood_bill.html (estimating that direct paired kidney donation could save Medicaid at least $\$ 220,000$ in dialysis costs per patient; also noting Congressional Budget Office estimation "that legalizing paired kidney donation would save about $\$ 30$ million over 5 years and $\$ 500$ million over 10 years.”); see Goodwin, The Body Market, supra note 57, at 634.

93. See Stella L. Smetanka, Who Will Protect the Disruptive Dialysis Patient, 32 AM. J. L. \& MED. 53, 54-55 (2006) (looking at the challenges facing a patient with end-stage renal disease and the dialysis industry in general).

94. See OrganDonor.gov, 2005 National Survey of Organ and Tissue Donation Attitudes and Behaviors Figure 6, http://www.organdonor.gov/survey2005/ (last visited Mar. 28, 2008):

Willingness to donate is high among Latinos (49.2\%), Asians (46.0\%), and Whites (44.8\%), but is significantly lower among Blacks (30.0\%). An estimate of the proportion of the population approachable for donation can be determined by multiplying the proportion willing to donate times the proportion of those who haven't granted permission to donate. Using this approach, one finds that $28.1 \%$ of Latinos haven't granted permission to donate, yet are willing to do so. Almost as great a proportion of Asians (26.2\%) fall into this category, but fewer Blacks $(19.8 \%)$ or Whites $(16.9 \%)$ do.

95. Id.; see also Random Samples: Who Donates Organs?, 309 SCI. 47 (2005) [hereinafter Random Samples] (suggesting that Black donor rates may be as low as $25 \%$ and attributing such to lack of trust); Study Evaluates Why Blacks Do Not Successfully Donate Kidneys, SCI. DAILY, May 9, 2007, http://www.sciencedaily.com/releases/2007/05/070508072842.htm (last visited Apr. 27, 2008).

96. The Organ Procurement and Transplant Network, Deceased Donors Recovered in the U.S. by Donor Ethnicity, http:/www.optn.org/latestData/rptData.asp (last visited Mar. 30, 2008) (choose Data, then National Data set; then choose category of donor, then deceased donor by ethnicity). 
roughly correlates with a $25 \%$ participation rate in the organ-procurement system. ${ }^{97}$ Assuming such, it is possible to predict the number of harvestable organs that might be created by an increase in Black participation. If Black participation increased to the current level of Hispanic participation, 2135 organs could be harvested per year-an increase of almost 1000 organs from the Black community alone. If Black participation rates rose to the level of the national average, 2362 organs could be harvested from their communities-an increase of almost 1230 organs per year. Lastly, if Black participation rates increased to a level commensurate with that of White organ donors, 2817 organs could be harvested from the Black community-an increase of more than 1680 organs per year. Even assuming a slightly less-than-perfect correlation between organ transplantation and lives saved, the potential beneficial impact of such a system is compelling.

There are several reasons why the above calculations might both over-and underestimate the actual increase in supply generated by the inclusion of racial preferences in organ procurement. The calculations do not account for any increases in donation resulting from non-Black populations. Yet allowing greater donor control over the allocation of their organs might create a broad stimulant to encourage organ-donor participation across all racial subgroups. For example, Hispanics might galvanize around the opportunity to help other Hispanics through directed donations, even if Hispanics do not demonstrate a similar distrust of the organ procurement and allocation system.

The calculations above may also overestimate the increase in organ supply. Individuals who do not become organ donors because of personal or religious beliefs relating to the sanctity of the human body are less likely to participate in organ donation regardless of racial preference. A similar response is paired to moral objections to organ donation. This thought experiment identifies but cannot resolve current information constraints that may accompany the racial and socioeconomic status of donors. ${ }^{98}$ As a result, individuals who do not donate because of information deficiencies or religious and medical fears of the procedure itself will likely remain outside of the system.

\section{IV}

\section{THE LEGAL RAMIFICATIONS OF USING RACIAL PREFERENCES TO SPUR BLACK PARTICIPATION IN ORGAN DONATION}

The Uniform Anatomical Gift Act (UAGA) established the process by which individuals may legally donate cadaveric organs. ${ }^{99}$ This Act was ratified by all states and the District of Columbia shortly after the first liver, pancreas,

97. Random Samples, supra note 95.

98. See, e.g., Why Blacks Do Not Donate More Organs, JET 15, Dec. 11, 1995, available at http://findarticles.com/p/articles/mi_m1355/is_n5_v89/ai_17829588 (last visited Mar. 31, 2008).

99. UNIFORM ANATOMICAL GIFT ACT §8A U.L.A. 69 (1968) [hereinafter UAGA]. 
and heart transplants. ${ }^{100}$ The UAGA permits a competent adult to "give all or part of [his] body" for certain designated purposes, including "transplantation, therapy, medical or dental education, research, or advancement of medical or dental science." ${ }^{101}$ The revised UAGA (1984), in compliance with NOTA, does not, however, allow the donor to receive "valuable consideration" for the transfer. ${ }^{102}$ NOTA added a federal measure on top of the UAGA regulatory framework, which states simply that "it shall be unlawful for any person to knowingly acquire, receive, or otherwise transfer any human organ for valuable consideration for use in human transplantation if the transfer affects interstate commerce. ${ }^{103}$ Both the UAGA and NOTA provide for criminal penalties and fines for violation of any provision within the laws. ${ }^{104}$

\section{A. Overcoming NOTA's Rigid Constraints: Is Promoting Racial Preferences a Legal Consideration?}

Neither the UAGA nor NOTA defines "valuable consideration." The transfer of money in exchange for an organ seems to fall clearly within the scope and intent of each, yet it is unclear whether the same holds true for lesstraditional forms of exchange and economic interests, such as the expression of racial preferences. From a historical point of view, the ability of an individual to express and promote his or her racial preferences has economic value. For a Black organ donor desiring to correct a form of social injustice by channeling an organ donation to a Black patient person, this "secondary economic value" 105 is in excess of the implicit gratification received from simple altruistic gift-giving. Does this secondary economic interest constitute valuable consideration? Or does it color the donor's intent to such a degree that his gift of life is no longer considered altruistic?

The value individuals place on race is not trivial and has been considered in insightful, but limited contexts, such as schooling, ${ }^{106}$ busing, ${ }^{107}$ and

100. UAGA prefatory note, 8A U.L.A. 4-7 (1987). Note that the early policy efforts to regulate organ transplantation occurred at the state rather than federal level as the UAGA was drafted by the National Conference of Commissioners on Uniform State Laws (NCCUSL).

101. CAL. HEALTH \& SAFETY CODE, $\S \S 7151,7153$ (2008).

102. Id. at $\S 7155$.

103. NOTA, supra note 23 .

104. Id. at $\S 274(\mathrm{e})(\mathrm{c})(2)$; UAGA, supra note 100 at $\S 5(\mathrm{f})$; TOM КOCH, SCARCE GOODS: JUSTICE, FAIRNESS AND ORGAN TRANSPLANTATION 50-71 (2002) (noting that in NOTA Congress standardized the imposition of a criminal fine or imprisonment across all fifty states).

105. "Secondary" only in the sense that it is not directly quantifiable in terms of traditional economic measures such as money. In economic terms, this is known as a "shadow value." As conceived, this shadow price is a form of opportunity cost that would be lost by not participating as an organ donor.

106. See, e.g., Nelson Lund, The Rehnquist Court's Pragmatic Approach to Civil Rights, 99 Nw. U. L. REV. 249, 279-87 (2004).

107. See, e.g., Darren Lenard Hutchinson, The Majoritarian Difficulty: Affirmative Action, Sodomy, and Supreme Court Politics, 23 LAW \& INEQ. 1, 28 n.162 (2005). 
accommodations. ${ }^{108}$ Determining the value of racial identity and its impact on individual decisions remains difficult. The AAOTS studies suggest that whether a Black person decides to become an organ donor may be related to his or her perceptions about the allocation and procurement system's equity. ${ }^{109}$ In economic terms, perceived inequity increases the cost of becoming an organ donor to Blacks. If this is correct, it costs Blacks more to participate in the organ procurement system than any other minority group, and Blacks receive on average fewer benefits of organ allocation. As a result, a cascade effect may emerge, whereby Blacks' perceptions of social injustice become reinforced and lead to even greater sensitivity to disparity in costs between themselves and non-Black donors. In essence, the greater cost of organ donation creates a disincentive for Black participation in the organ-procurement system. Ferreting out the exact contours of this economic relationship are beyond the scope of this article. The important point is simply that Black organ donors appear to place some value on the perceived inequities of the organ-transfer system.

To further unpack this theory, we examined Black self-help or rescue models from the civil-rights era. That Blacks might place an economic value on their racial identity is consistent with the civil-rights legacy of individuals foregoing their own self-interest in response to "group" challenges or to promote "group" uplift. During the 1950s, many Black business owners and workers, including those who paved the way for litigation in Brown v. Board of Education, ${ }^{110}$ chose to sacrifice potential profits in support of movements to

108. See, e.g., Lior Jacob Strahilevitz, Information Asymmetries and the Rights to Exclude, 104 MiCH. L. REV. 1835, 1867-68 (2006).

109. See supra I.B.

110. Brown v. Board of Education was a composite of several lawsuits against school districts and although most of the cases named children, with Briggs v. Elliot as an exception, those who actually coordinated the cases and economically underwrote the efforts on behalf of Black children were business owners and laborers employed at what were considered respected jobs at the time. This excerpt of an interview with Mrs. Briggs (a litigant) helps to place in context what the litigants and their supporters endured (grammar unaltered and without emphasis):

Well, it happened to me. I was working at Summerton Motel, and this man, the work us, Greenborough, he work us real good. And the White Council, of Summerton, I think they call it the White Council, they came down there and told him that, if he didn't fire the women who signed the petition, that they would close the business down. They won't let the trucks come in and deliver. So then he called us in, and asked all who that signed the petition, would we take our name off the petition in order to work. After all, we had to pay $\$ 5$ to take our name off the petition. I told him, no, I didn't want to do that, because we be hurting the children, and I rather give my job up, and keep my name on there. So in about two week's time, I was fired.

Not only me, the rest of them who had anything to do with the petition, they all was fired. Annie Gibson was fired, and many more, during that time too. They-a lot of colored people on the white man place-they made them move, because they signed the petition. So they didn't have, well I guess they find a place to go. But when you live on white man place, partly all your life, and when you sign a petition for your children to do better, they told them, said, "Well you got to go. Else take the name off the petition." And many of the people decided they did not want to take the name off, and they did not take the name off.

http://www.teachersdomain.org/assets/wgbh/iml04/iml04_doc_fullbriggs/iml04_doc_fullbriggs.pdf. 
provide equitable accommodations and funding for schools. ${ }^{11}$ In real economic terms, they suffered. Racial uplift had its costs, but it seems that to the participants in the civil-rights movement, "race advancement" was more valuable than money.

Black entertainers joined in by boycotting segregated music venues in the South, incurring economic losses and hostility from agents, touring, record companies and the broader entertainment industry. ${ }^{12}$ According to Bennetta Jules-Rosette, Josephine Baker insisted "[f]rom the outset . . . that she perform only for integrated audiences at every venue." ${ }^{113}$ She even insisted that curfew and segregation ordinances be lifted before she would perform. ${ }^{114}$ Baker was not alone. Shortly before a concert in Augusta, Georgia, Ray Charles decided that he could no longer tolerate performing at segregated venues. In a recent biography, Michael Lydon describes Charles' frustration. A telegram informing Charles that his performance at Paine College would be to White students only, invoked this response, "I had to stand behind my principles and help the students in their fight" for desegregation. ${ }^{115}$ His boycott came at a cost, as he was sued by concert promoters for breach of contract. ${ }^{116}$

Maids, shopkeepers, school teachers, and others across socioeconomic strata also risked the political and economic fallout from arrests and incarcerations resulting from marches and protests related specifically to race-focused ideals, such as the integration of schools in New Orleans and of lunch counters in Tennessee. ${ }^{17}$ Indeed, the infamous walk in the spring of 1965 across the Edmund Pettus Bridge, commonly known as "Bloody Sunday," stands out as a moment that demonstrates in social, economic, and political contexts what Blacks were willing to wager for the right of other Blacks to vote. ${ }^{118}$ The hundreds that marched across the bridge were not simply advocating for their

111. Even musicians and artists boycotted profitable music tours in the South because of discrimination against local Blacks. E.g., Theodore Strongin, Boycott Efforts in Arts Continue, N.Y. TIMES, Mar. 11, 1964.

112. For example, Josephine Baker was derided as being "difficult" and too political because she refused to perform in segregated music venues. See BENNETTA JULES-ROSETTE, JOSEPHINE BAKER IN ART AND LIFE, 221-22 (2007). Marian Anderson, Paul Robeson, Hazel Scott, Ray Charles, and other preeminent Black musicians boycotted segregated venues. See ALLAN KEILER, MARIAN ANDERSON: A SINGER'S JOURNEY 255-59 (2000) (documenting Anderson's decision to boycott segregated music venues and the political fallout that transpired). See also MICHAEL LYDON, RAY CHARLES: MAN AND MUSIC 196-97 (2004).

113. See JULES-ROSETTE, supra note 112, at 221.

114. Id.

115. See LYDON, supra note 112 at 196-97.

116. Id. at 197.

117. There is real economic value to boycotts. They obviously impact business from those who would otherwise go to the lunch counter, but they also symbolize the potential for expanded consumers. See, e.g., JOHN S. DRYZEK, DELIBERATIVE DEMOCRACY AND BEYOND: LIBERALS, CRITICS, CONTESTATIONS 51-52 (2000).

118. See U.S. Department of State, Free At LAST: ThE U.S. Civil Rights MovemENT, 57-61 (2008), available at http:/www.america.gov/media/pdf/books/free-at-last.pdf; Selma-to-Montgomery March, U.S. NATIONAL PARK SERVICE, available at http://www.nps.gov/nr/travel/civilrights/al4.htm. 
individual rights to vote, but something more. ${ }^{119}$ The decision to march was calculated, though, and Blacks were not naïve about the risks they exposed themselves and their children to for the sake of liberating other Blacks. ${ }^{120}$

One way of observing the economic value Blacks place on race considerations is by understanding where Blacks donate their financial resources. Blacks give $25 \%$ more of their discretionary income to charity than Whites do. ${ }^{121}$ One could interpret this as Blacks being, on average, more generous than Whites, at least in terms of their money. Their giving may also be linked to identity causes and movements. Blacks are more likely to donate to the NAACP and other not-for-profit organizations that promote civil-rights agendas than their White counterparts. ${ }^{122}$ This may be either the cause or the result of more targeted public-relations campaigns. ${ }^{123}$

Altruism and individual identity are inextricably linked. An individual is most likely to donate to those organizations and causes that promote the expression of his or her own identity. ${ }^{124}$ This may be because "both peer pressure and belief in an institution play a role when donors give generously." But the trend might be even broader. For instance, Blacks who make between $\$ 30,000$ and $\$ 50,000$ donate an average of $\$ 528$ annually, compared with $\$ 462$ donated by their White counterparts in the same income range. ${ }^{126}$

But the question remains: Why are Blacks, who appear more generous and altruistic than Whites with comparable spending power, not equally generous with their organs? The simplest explanation is that Blacks can control who receives their money but cannot control who receives their organs. Despite increases in organ donors by $26 \%$ in the past twelve years, Blacks' participation is miniscule compared to other minority groups. ${ }^{127}$

119. Blacks were met with such extreme violence that the incident made international news.

120. FREE AT LAST, supra, note 118.

121. Eric Gondawe, Charity Statistics in the US, http://www.zambian.com/bethel/orphanageministry-resources-online/html/charity-statistics.html (last visited Dec. 1, 2007).

122. Alice Lukens, The Science of Smart Giving: Organizers of a New Program in Baltimore Want Wealthier African-Americans to Embrace Setting Up Foundations and Trusts, THE BALTIMORE SUN, Jan. 10, 2001, at 1A.

123. The question is most recently addressed by bloggers debating the fairness of the NAACP using advertising slogans insinuating that donations are going to the Jena Six Defense Fund, when in fact such donations travel to a NAACP general fund. Too Sense: Race, Politics, and Hip Hop, NAACP Alters Its Website to Link to Jena Six Defense Fund, available at http://halfricanrevolution.blogspot.com/2007/07/is-national-naacp-profiteering-off-jena_27.html (last visited March 31, 2008).

124. Alice Lukens, supra, note 122.

125. See Susan Jacoby, Why Do We Donate? It's Personal, N.Y. TIMES, Dec. 9, 1997, at G1.

126. Id.

127. Random Samples, supra note 95 ("Whereas about $62 \%$ of whites and Asians are willing to donate organs, the figure falls to $47 \%$ among Hispanics and $25 \%$ among Blacks."). 


\section{B. Racial Preferences as Valued Consideration}

The UNOS attempts to explain the contours of "valuable consideration" using the notion of donative intent. In essence, this distinction suggests that donations given in response to "valuable consideration" do not have the requisite altruistic intent. Some have gone so far as to suggest that "a preference might be considered "valuable consideration' for an organ donation," and thus, "to avoid any confusion, laws that now ban compensation for organs should be amended to add this form of reciprocity/insurance to the list already exempted from such bans." ${ }^{128}$ One thing is certain-determining donative intent is a tenuous proposition. Even within the UNOS policy itself, contradictions exist. For example, the UNOS condones "living donation arrangements" as not involving "valuable consideration," but condemns paired kidney transplants as counter to the intention of organ legislation even though in both cases the intentions of individual donors cases appear identical. ${ }^{129}$

Of course, it can be argued that using racial preferences to encourage Blacks to become organ donors does not provide valuable consideration; rather, it merely directs donations toward a particular subpopulation. Unlike the case of a contract or paired transplant, donors would remain unaware of the identity of their organ recipient aside from the recipient's race. In turn, the relationship between donor and recipient remains attenuated enough that incentives for extra-legal arrangements are of no concern. ${ }^{130}$

\section{The Tension Between Promoting Racial Preferences and Equality: Does \\ Using Race to Promote Organ Donation Raise Constitutional Equal Protection Issues?}

The values individuals place on racial preferences often lie in tension with democratic principles promoting equality across racial strata. But this was not always the case. Through the 1950s and 1960s, legal segregation gave deference to individual racial preferences at the expense of equality, especially in elementary, secondary, and higher education in southern states. ${ }^{131}$ Because the Supreme Court initially interpreted separate as equal in Plessy v. Ferguson, ${ }^{132}$ this tension did not create constitutional concerns. ${ }^{133}$ In turn, the Court protected the expression of White racial preferences and subgroup interest at the detriment of Blacks. In Brown v. Board of Education, the Court reversed its

128. Mark S. Nadel \& Caroline A. Nadel, Commentary, Using Reciprocity to Motivate Organ Donations, 5 YAle J. HeALTH POL'Y LAW \& ETHICS 293, 321 (2005).

129. See Goodwin, The Body Market, supra note 57.

130. This argument is of primary importance in response to those arguing against commodification of organs because of the risk of economic coercion. Gilbert Meileander, Gifts of the Body, NEW ATLANTIS 25 (Summer 2006).

131. See generally Alfreda A. Sellers Diamond, Black, White, Brown, Green, and Fordice: the Flavor of Higher Education in Louisiana and Mississippi, 5 HASTINGS RACE \& POVERTY L.J. 57, 61 (2008).

132. Plessy v. Ferguson, 163 U.S. 537 (1896).

133. Id. at 548 . 
prior jurisprudence and refused to give deference to the expression of racial preferences when doing so was at the expense of equality across races. ${ }^{134}$ Such concerns arose in the context of Fourteenth Amendment equal-protection claims. ${ }^{135}$

Allowing organ donors to select the race of their recipients shifts the decision-making entity in organ allocation from the government to the individual. What remains, however, is to contemplate what role, if any, the government then has in enforcing antidiscrimination policies in the context of organ transfers. The constitutionality of government action is reviewed under strict scrutiny when it distributes burdens or benefits on the basis of racial classification. ${ }^{136}$ As a threshold matter, the constitutionality of a race-based solution to organ supply which places the use of racial criteria at the discretion of potential donors should escape strict-scrutiny analysis. However, the state's role in such a program would likely not be de minimis, as the burdens of administering the race-based program might be assumed by the government. ${ }^{137}$ As such, it may be appropriate to analyze the constitutionality of the program in light of the strict-scrutiny framework, regardless of the nongovernmental nature of the decision-maker.

The Court stated in Grutter v. Bollinger that "[w]hen race-based action is necessary to further a compelling state interest such action does not violate the constitutional guarantee of equal protection so long as the narrow-tailoring requirement is also satisfied." ${ }^{138}$ In the educational context, the Court has found that two such compelling government interests are remedying past intentional discrimination and increasing student body diversity in higher education. ${ }^{139}$ As previously stated, the Court has found diversity in higher education to be a compelling interest under a strict-scrutiny analysis. ${ }^{140}$ Allowing the use of racial preferences in an organ transfer system may be easily seen as a means to remedy past discrimination or save a life. Organ diversity, however, does not squarely map onto the Court's discussion of diversity as a compelling state interest under a constitutional strict- scrutiny analysis. According to Justice Roberts, "[t]he diversity interest was not focused on race alone but encompassed 'all factors that may contribute to student body diversity." ${ }^{\prime 141}$ In

134. 347 U.S. 483, 495 (1954).

135. Id. Title VII of the Civil Rights Act of 1964, 42 U.S.C. $\S 2000 \mathrm{e}-2(a)(1)-(2)$ (2000), likewise directly addresses racial preferences by eliminating practices that lead to the disparate treatment of employees or job applicants on the basis of their race, color, religion, sex, or national origin.

136. City of Richmond v. J.A. Croson Co., 488 U.S. 469, 519 (1989).

137. We are agnostic on this matter. It might be that the government is not the best entity to implement a progressive organ-transplant policy. These issues might be better dealt with by private organizations.

138. Grutter v. Bollinger, 539 U.S. 306, 326-27 (2003).

139. See, e.g., 488 U.S. 469; Regents of Univ. of Cal. v. Bakke, 438 U.S. 265 (1978).

140. Grutter, 539 U.S. at 328.

141. Parents Involved in Community Sch. v. Seattle Sch. Dist. No. 1., 551 U.S. 701, 703 (quoting Grutter, 539 U.S. at 337). 
Grutter, the Court held that a state law-school admissions process was narrowly tailored to obtaining the educational benefits that flow from a diverse student body, even though it denied certain students admission to the law school on the basis of race. ${ }^{142}$ The implication of Grutter is that a state may constitutionally restrict an individual's choice in attending a particular institution if a compelling diversity-based reason exists to do so. In the case of organ donation, no compelling diversity-based reason exists upon which limitations on individual choice may be justified. An organ recipient gains no additional utility by receiving an organ from a donor of a different race. Unlike racial preference in the education context, organ diversity does not seem a compelling reason to restrict individual choice. Rather, individuals should be allowed to choose if, and within broad categories, to whom they wish to donate their organs post mortem. $^{143}$

\section{Pitfalls of Race Preference?}

Every institution has its drawbacks. ${ }^{14}$ Some institutions are far more burdened than others and thus become less efficient and effective over time. ${ }^{145}$ Other institutions become the ideal (or at least less-burdened) mediums for transactions typically reserved for first-choice institutions. ${ }^{146}$ What is important in each case is to match supply with demand. ${ }^{147}$ Even in the best cases of equilibrium there may be externalities.

At first blush, one might want to analogize to the use of racial preferences in reproductive markets as another example of a race-positive transfer system. One drawback to comparing race preferences in organ versus reproductive markets, though, is that the two do not map evenly. The use of racial preferences in the adoption process and selection of sperm for artificial insemination is a family-planning decision. Though there is no explicit reference to family-planning decisions in the Constitution, these are the types of rights to which the government generally defers to individual choice. ${ }^{148}$ Individual choices expressing racial preferences in organ markets, however, are not choices regarding family planning. Instead, such decisions center on issues of public health and safety-realms in which government regulation typically trumps individual preference. ${ }^{149}$ Thus, critics of our proposal might argue that the state

142. Grutter, 539 U.S. at 337.

143. As living donors, individuals may choose to whom they wish to donate within the most narrow category possible-selection of an actual recipient.

144. See Neil K. Komesar, Law's Limits: The Rule of LAW AND the Supply and Demand OF RIGHTS (2001).

145. Id.

146. $I d$.

147. $I d$.

148. See, e.g., Marjorie Maguire Shultz, Contractual Ordering of Marriage: A New Model for State Policy, 70 CAL. L. REV. 204 (1982).

149. Buck v. Bell offers a troubling example of state interest through its public-health police power trumping individual choice, even in the realm of reproduction. 274 U.S. 200, 207-08 (1927). In that case, 
interest in maintaining a color-blind system of organ transfer is consistent with laws against organ commodification and hard-won civil-rights battles and should thus be upheld.

But if we unpack the Court's decisions upon which such criticisms are based, it is clear that honoring racial preferences leads to a protection of individual choice through the privacy interest "implicit in the meaning of the Bill of Rights." ${ }^{150}$ In Griswold v. Connecticut, the Court held that this fundamental right encompassed a married couple's right to privacy when making family-planning decisions, including the decision to choose to use birth control. ${ }^{151}$ Similarly, in Roe v. Wade and Planned Parenthood of Southeastern Pennsylvania. v. Casey, ${ }^{152}$ the Court recognized certain areas over which individuals have private control.

Allowing racial preferences in deciding to whom an organ is given is not inconsistent with these principles. Critics might argue that race preference in organ transplantation is a form of reverse discrimination or that it would approve overt discrimination against Blacks by Whites who might choose to withhold their organs from Blacks (and all minorities). These arguments are seductive and commonly evoked in affirmative-action debates. ${ }^{153}$ But do they have any real traction in the context of organ transplantation? These issues may be outside of the ambit of the Good Samaritan principles codified in NOTA and the application of that ethos in American culture and law. The truth is that we do not enforce a duty to rescue; it is absent from our common-law tradition. ${ }^{154}$

\section{V \\ CONCLUSION}

We proposed a simple thought experiment that, if viable, could serve as a solution to help ameliorate the problem of organ supply, particularly for Blacks.

the state's interest in sterilizing "socially unfit" women and girls was deemed to appropriately fall within the state's authority to protect and promote public health and safety. Id. at 207. According to Justice Oliver Wendell Holmes, the authority granted to states to compel inoculations was the same authority to compel sterilizations. $I d$. at 207. Some scholars argue that Skinner overturns Buck, but on careful reading it seems clear that the decision remains an enforceable artifact from a problematic era. See, e.g., Elizabeth F. Emens, Intimate Discrimination: The State's Role in Accidents of Sex and Love, 122 HARV. L. REV. 1307, 1316 n.23 (2009); Dean M. Hashimoto, Science As Mythology in Constitutional Law, 76 OR. L. REV. 111, 136 (1997); Kimberly M. Mutcherson, Making Mommies: Law, Pre-implantation Genetic Diagnosis, and the Complications of Pre-Motherhood, 18 COLUM. J. GENDER \& L. 313, 342 (2008).

150. Sarah Tomkowiak, Reconciling Principles and Prescriptions: Do Pharmacist Refusal Clauses Strike the Appropriate Balance Between Pharmacists' and Patient's Rights, 2007 U. ILL. L. REV. 1329, 1333 (2007) (the author proposes ways to ensure women have access to prescribed birth control while also respecting pharmacists' moral beliefs).

151. 381 U.S. 479 (1965); see also Sarah Tomkowiak, supra note 150, at 1332-34.

152. 505 U.S. 833 (1992).

153. See, e.g., Charles A. Sullivan, Circling Back to the Obvious: The Convergence of Traditional and Reverse Discrimination in Title VII Proof, 46 WM. \& MARY L. REV. 1031 (2004).

154. See Michele Goodwin, My Sister's Keeper?: Law, Children, and Compelled Donation, 29 W. NEW ENG. L. REV. 357, 365 (2007). 
The hypothesis pushing this article is that by allowing individual control over the recipients of their donated organs, more people will likely become donors. The idea is presently captured in the appeal of internet-based organ-donation sites like Matchingdonor.com. Self-selection is a tipping point for potential Black donors, with significant economic and social consequences. Not surprisingly, associations with any affinity group might help to facilitate an overall increase in organ donations. One could imagine Polish church groups in Chicago participating in an organ-sharing program or Albanian fraternities in California, and Cape Verdean community groups in Rhode Island doing the same.

Blacks remain suspicious of the U.S. medical system in general and of the transplant system in particular. In large part, their discomfort might stem from a history of being subjects of medical experiments without consent (or knowledge) and the facts that they wait longer for organs than any other racial group and that they experience the highest rates of death among all participants in the U.S. transplant system. Dismissing such concerns as irrational hyperbole fails to take into account the actual disparities resulting from the current transplant regime.

The use of racial preferences as a decision-making criterion addresses the distributional problems of organ allocation and could promote parity by giving organ suppliers some sense of control. Preferences are consistent with the way in which regulations function in other areas of biological transfer, such as the adoption process and the purchase of reproductive goods such as ova, sperm, and the renting of wombs for artificial insemination. The altruistic system of organ procurement and allocation is failing to provide an adequate supply of organs for those in need of life-saving transplantation. The critical issues, as of yet unresolved by the UNOS are how to increase organ supply and, holding all else equal, how to overcome resistance to organ sharing. In this article, we document that a significant, if not prevailing, reason for lower participation rates in Black communities is an underlying distrust of the transplant system. Based on the conclusions drawn from our hypotheses, permitting racial preferences in organ allocation directly addresses the concerns raised by Blacks. 